\title{
Pendampingan Entrepreneurship Budidaya dan Pemasaran Ikan Cupang (Betta sp.) oleh Alumni Jurusan Akuakultur, Universitas Bangka Belitung
}

\author{
Andri Kurniawan ${ }^{1}$ \\ ${ }^{1}$ Jurusan Akuakultur, Universitas Bangka Belitung \\ E-mail: andri_pangkal@yahoo.co.id
}

\begin{abstract}
Abstrak
Pendampingan kewirausahaan atau entrepreneurship terhadap gagasan usaha alumni adalah dharma yang tidak dapat dilepaskan dari kewajiban dan pengabdian seorang dosen sebagai bentuk dedikasinya terhadap kemandirian dan eksistensi alumni di masyarakat. Kegiatan pengabdian ini bertujuan untuk memberikan pendampingan kepada alumni Jurusan Akuakultur, Universitas Bangka Belitung dalam merintis dan membangun usaha budidaya dan pemasaran ikan cupang (Betta sp.). Kegiatan ini dilakukan melalui tahapan pengenalan potensi budidaya ikan hias, membangun relasi terhadap pembudidaya dan pemasar ikan hias, dan menyusun strategi promosi dalam perintisan usaha, pemasaran, dan pengembangan usaha alumni. Kegiatan pendampingan ini menghasilkan satu rintisan usaha budidaya dan pemasaran ikan hias, khususnya ikan cupang dengan nama Exotic Betta. Usaha yang dirintis dalam waktu tiga bulan telah menunjukkan prospek usaha dengan adanya peningkatan penjualan dan perluasan wilayah pemasaran, baik di Kota Pangkalpinang dan kabupaten yang ada di Pulau Bangka hingga di wilayah luar Pulau Bangka. Promosi dan pemasaran ikan cupang Exotic Betta yang dilakukan melalui media online dan media sosial telah membuat unit usaha ini cepat dikenal oleh para penghobi ikan cupang. Pengembangan usaha perlu dilakukan dengan diversifikasi komoditas untuk meningkatkan dan mengembangkan usaha pemasaran ikan hias.
\end{abstract}

Kata kunci: alumi, entrepreneurship, ikan cupang, pengabdian dosen.

\begin{abstract}
Entrepreneurship assistance to alumnus's business ideas is a practice that cannot be separated from the obligations and devotion of a lecturer as a form of dedication to the independence and existence of alumnus in society. This service activity aimed to provide assistance to alumni of the Aquaculture Department, Bangka Belitung University in pioneering and building a betta fish (Betta sp.) cultivation and marketing business. This activity was carried out through the stages of introducing the potential for ornamental fish cultivation, building relationships with ornamental fish cultivators and marketers, and formulating promotional strategies in starting businesses, marketing, and developing alumni businesses. This mentoring activity resulted in a pilot business for ornamental fish cultivation and marketing, especially for betta fish, namely the Exotic Betta. The business that was initiated within three months has shown business prospects with an increase in sales and expansion of the marketing area, both in Pangkalpinang City and regencies in Bangka Island to areas outside Bangka Island. The promotion and marketing of the Exotic Betta betta fish through online media and social media has made this business unit quickly recognized by betta fish hobbyists. Business development needs to be done by diversifying commodities to increase and develop marketing business for ornamental fish.
\end{abstract}

Keywords: alumnus, entrepreneurship, betta fish, dedication of lecturer 


\section{PENDAHULUAN}

Eksistensi alumni merupakan salah satu manifestasi dari proses pembelajaran yang dilakukan di suatu perguruan tinggi. Alumni sebagai produk akhir yang dihasilkan oleh perguruan tinggi berperan penting sebagai tolak ukur kualitas dari almamaternya. Upaya strategis harus tetap dilakukan oleh suatu perguruan tinggi dalam rangka memperhatikan keberadaan alumni karena menjadi salah satu indikator evaluasi dan tolak ukur kesuksesan penyelenggaraan pendidikan di perguruan tinggi [1].

Kontribusi alumni adalah parameter penting untuk menilai eksistensi alumni di dalam mengimplementasikan ilmu dan pengalaman yang diperolehnya selama proses pembelajaran di kampus. Salah satunya adalah peranan alumni di dunia pekerjaan, yaitu kemampuan alumni berwirausaha sebagai upaya membangun kemandirian diri, menghadirkan solusi untuk mengurangi pengangguran terpelajar, dan membuka kesempatan kerja bagi pihak lainnya.

Kewirausahaan atau entrepreneurship dianggap sebagai suatu proses kreatif dan inovatif di dalam mengelola potensi sumber daya untuk menghasilkan nilai tambah dalam kemanfaatan, mutu, ataupun nilai ekonominya. Proses membangun entrepreneurship bagi alumni adalah sebuah tantangan sekaligus seni membentuk alumni yang taktis, praktis, dan optimis untuk mengisi celah-celah peluang usaha yang tersedia dan/atau membuat peluang usaha tersebut tersedia di masyarakat.

Peranan universitas dalam memotivasi para sarjananya menjadi young entrepreneur merupakan faktor pendorong pertumbuhan jiwa kewirausahaan [2]. Hal ini yang menjadi pemikiran bahwa Jurusan Akuakultur, Universitas Bangka Belitung harus berkontribusi di dalam pendampingan praktis bagi alumni untuk berwirausaha. Kontribusi ini bertujuan untuk mengupayakan munculnya jiwa entrepreneurship, khususnya di dalam diri alumni yang dirasa belum tumbuh dengan baik. Permasalahan yang terkadang menjadi hambatan di dalam membangun usaha baru bagi alumni adalah hambatan mental (mental block) oleh psikologi pribadi maupun lingkungannya. Sejumlah mental block yang dapat menghambat pengembangan jiwa wirausaha antara lain adalah rendahnya motivasi diri untuk menghadirkan solusi ekonomi secara mandiri (job creator) dan lebih menggantungkan harapan sebagai pencari kerja (job seeker). Rendahnya motivasi ini dihubung-hubungkan dengan faktor lain seperti permodalan, minimnya pengalaman, ide yang banyak tetapi tidak mampu dieksekusi, dan terbatasnya relasi sehingga semakin menghambat pengembangan diri di dalam memulai suatu usaha.

Bertitik tolak dari hal tersebut, maka kegiatan pengabdian berupa pendampingan entrepreneurship budidaya dan pemasaran ikan cupang (Betta sp.) ini dilakukan sebagai suatu dharma pengabdian kepada masyarakat oleh dosen untuk mendukung tumbuhnya wirausahawan muda alumni Jurusan Akuakultur, Universitas Bangka Belitung.

\section{METODE}

Kegiatan pengabdian masyarakat ini dilakukan dalam bentuk pendampingan budidaya dan pemasaran ikan cupang (Betta sp.) yang dilakukan di Kota Pangkalpinang, Provinsi Kepulauan Bangka Belitung pada Bulan Agustus-Oktober 2020. Kegiatan ini meliputi tahapan pendampingan gagasan, pendampingan teknis, serta pendampingan pemasaran. Metode di dalam tahapan pendampingan gagasan dilakukan dengan analisis SWOT (Strength, Weakness, Opportunity, Threat). Metode di dalam tahapan pendampigan teknis dan pemasaran dilakukan melalui praktik, pembinaan, dan pendampingan di dalam teknis pengembangan budidaya ikan cupang dan pemasarannya. Hasil dari kegiatan pengabdian ini dideskripsikan dalam bentuk tabel, grafik, maupun foto dokumentasi sehingga dapat memberikan gambaran dan capaian dari kegiatan pengabdian masyarakat tersebut. 


\section{HASIL DAN PEMBAHASAN}

1. Elaborasi Permasalahan Entrepeneurship Alumni

Langkah awal kegiatan pendampingan adalah mengelaborasi permasalahan yang dialami oleh alumni Jurusan Akuakultur di dalam usaha untuk memulai kegiatan kewirausahaan. Hasil kegiatan pendampingan menunjukkan bahwa motivasi dan modal usaha merupakan masalah utama yang dialami oleh alumni. Permasalahan motivasi dapat dicarikan penyelesaiannya melalui pendampingan gagasan, sedangkan permasalahan modal dapat dicarikan penyelesaiannya melalui iuran bersama secara sukarela, meskipun jumlahnya masih terbatas.

\section{Pendampingan Gagasan}

Pendampingan gagasan yang dilakukan merupakan suatu kegiatan elaboratif untuk menemukan ide usaha yang dapat berpotensi dijalankan dan dikembangkan. Prospek dari ide usaha dapat diamati dari tren permintaan komoditas yang dibutuhkan oleh konsumen atau buyer.

Hasil dari kegiatan ini menghasilkan beberapa ide usaha dan gagasan yang diterima sebagai suatu ide implementatif adalah usaha di dalam bidang budidaya khususnya ikan hias, yaitu ikan cupang (Betta sp.). Metode analisis yang dilakukan untuk menghasilkan gagasan tersebut adalah analisis SWOT. Metode analisis SWOT adalah evaluasi terhadap keseluruhan kekuatan, kelemahan, peluang, dan ancaman [3]. Diskursus ini dilakukan untuk menjadi pertimbangan terhadap kekuatan, kelemahan, peluang, dan ancaman dalam usaha sehingga pengambilan keputusan usaha dapat lebih tepat dan meminimalkan risiko negatif yang lebih besar. Hasil diskursus yang diperoleh melalui analisis SWOT ditampilkan pada Tabel 1.

Tabel 1. Hasil analisis SWOT

\begin{tabular}{|c|c|}
\hline Strength (kekuatan) & Weakness (kelemahan) \\
\hline 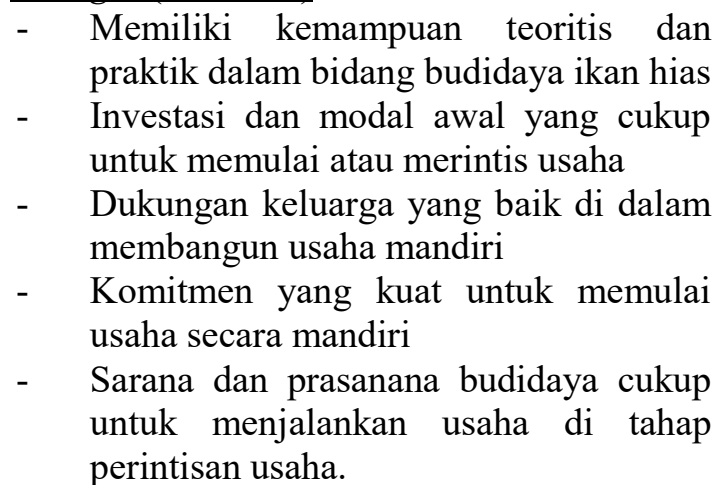 & $\begin{array}{l}\text { - Modal yang terbatas untuk membuat } \\
\text { usaha langsung memasuki skala besar. } \\
\text { Modal yang besar tersebut dibutuhkan } \\
\text { dalam membangun etalase untuk men- } \\
\text { display ikan hias. }\end{array}$ \\
\hline $\begin{array}{l}\text { Opportunity (peluang) } \\
\text { - } \\
\text { Peluang usaha ikan cupang adalah } \\
\text { permintaan yang tinggi oleh para hobiis } \\
\text { Harga jual yang baik dan tren } \\
\text { peminatan ikan cupang tumbuh kembali } \\
\text { karena munculnya strain-strain baru } \\
\text { yang memiliki corak warna bagus dan } \\
\text { bervariasi } \\
\text { Penerimaan keuntungan dan sirkulasi } \\
\text { modal cepat } \\
\text { Peluang usaha ini terlihat dari supplier } \\
\text { yang terbatas untuk memasok ikan } \\
\text { cupang sesuai permintaan pembeli atau } \\
\text { hobiis }\end{array}$ & 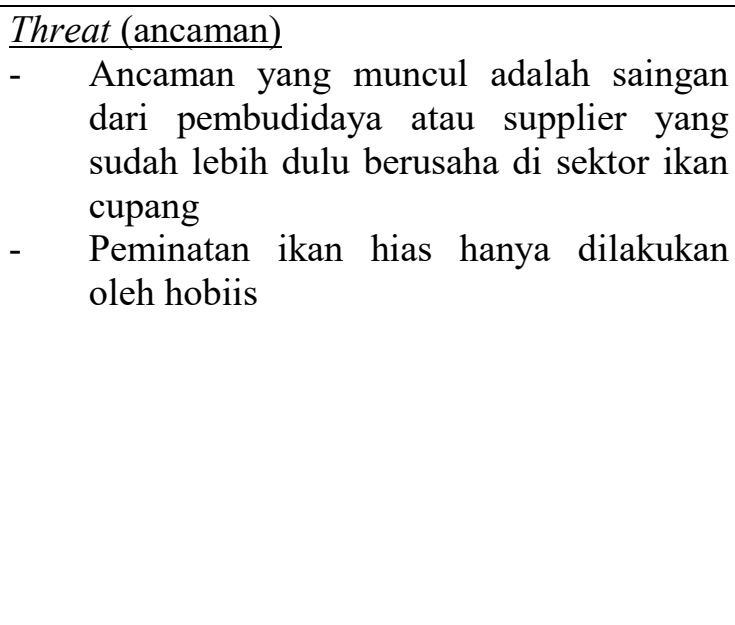 \\
\hline
\end{tabular}


Analisis SWOT yang dilakukan menjadi dasar pertimbangan pengambilan keputusan untuk menjalankan ide usaha ikan cupang dengan memperhatikan sebesar-besarnya kekuatan dan peluang yang tersedia dengan tetap memperhatikan kelemahan dan ancaman yang ada.

\section{Pendampingan Teknis}

Pendampingan teknis yang disampaikan lebih mengarah pada penguatan semangat dan mental berwirausaha. Pendampingan teknis yang dilakukan berupa kegiatan brainstorming, penyamaan persepsi tentang tujuan wirausaha, dan langkah-langkah berwirausaha. Kegiatan pendampingan teknis juga dilakukan dengan diskusi tentang budidaya ikan cupang dan pakan alami, serta manajemen pemasaran (Gambar 1).

Hasil yang diperoleh dari pelaksanaan kegiatan pendampingan teknis antara lain dapat diamati dari bertumbuhnya jiwa dan semangat wirausaha alumni; kesamaan persepsi tentang tujuan wirausaha, yaitu bukan hanya aspek ekonomi, namun juga keberkahan dan kontribusi kebaikan bagi orang lain; serta terwujudnya langkah taktis, sistematis, dan strategis untuk memulai usaha budidaya dan pemasaran ikan cupang dimulai dari persiapan, membangun jaringan usaha, dan strategi pemasaran.

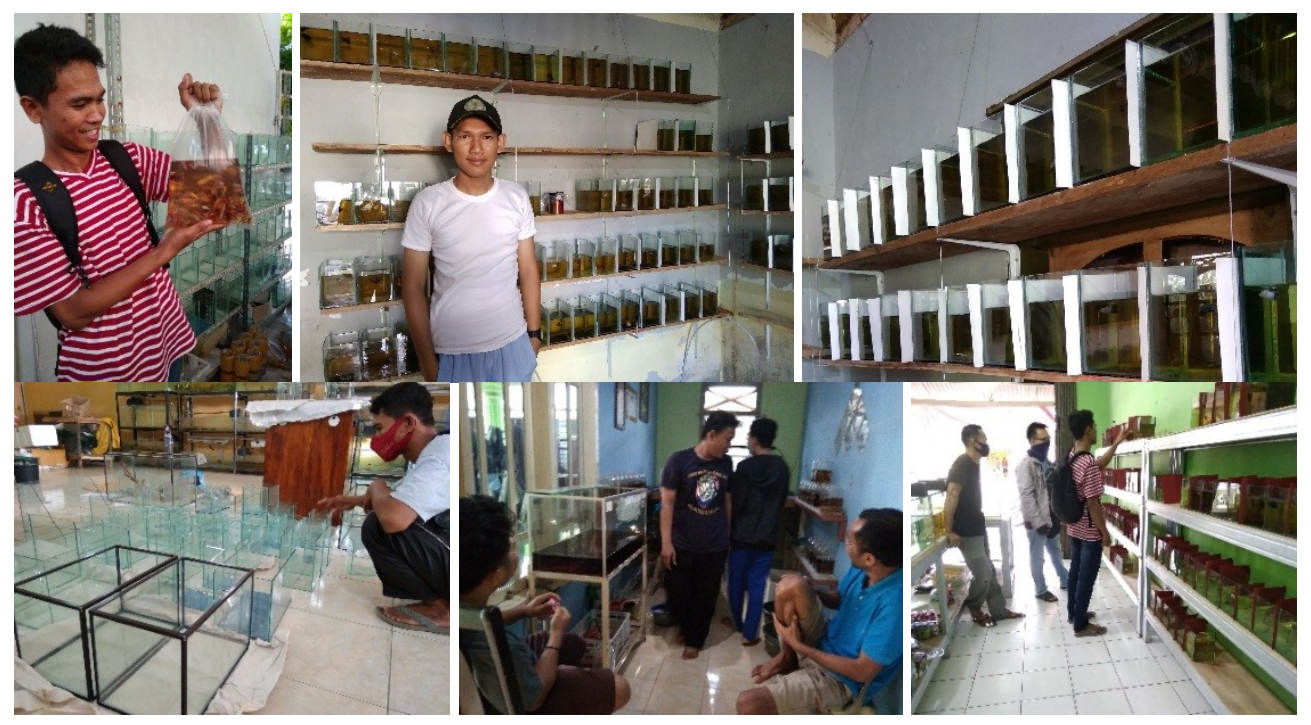

Gambar 1. Kegiatan Pendampingan Teknis

4. Pendampingan Pemasaran

Kegiatan pendampingan pemasaran yang telah dilakukan adalah berupa pembuatan nama dan logo usaha, yaitu Exotic Betta (Gambar 2) serta pemasaran yang dilakukan melalui media online dan media sosial.

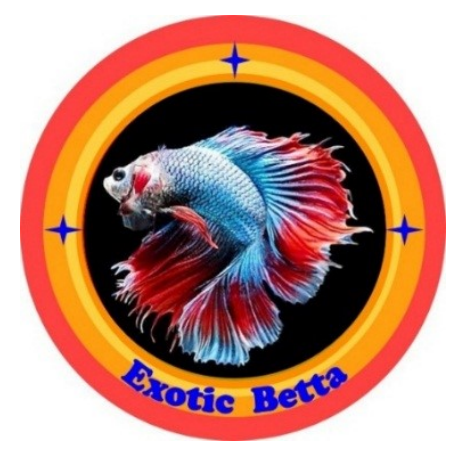

Gambar 2. Logo Exotic Betta 
Kegiatan pemasaran yang dilakukan telah mampu menghasilkan perkembangan usaha dalam kurun waktu tiga bulan, yaitu Agustus-Oktober. Justifikasi tersebut diindikasikan dengan peningkatan jumlah pembeli potensial dan pelanggan (Gambar 3), jumlah ikan yang dijual (Gambar 4), dan jangkauan daerah pemasaran (Gambar 5).

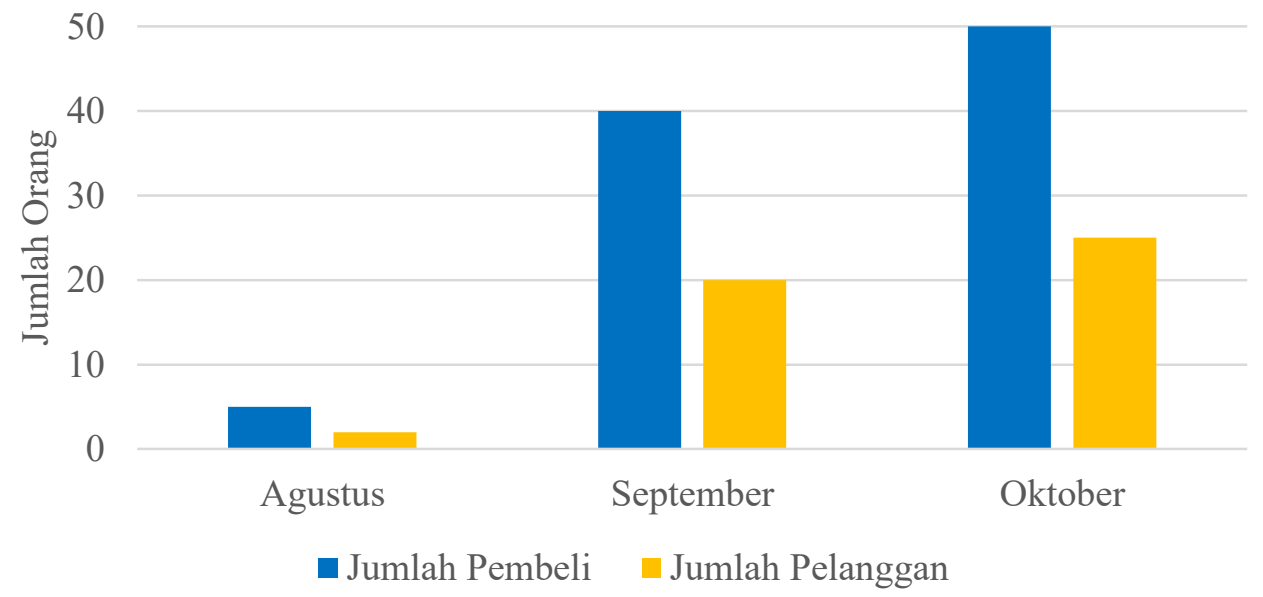

Gambar 3. Jumlah Pembeli Potensial dan Pelanggan.

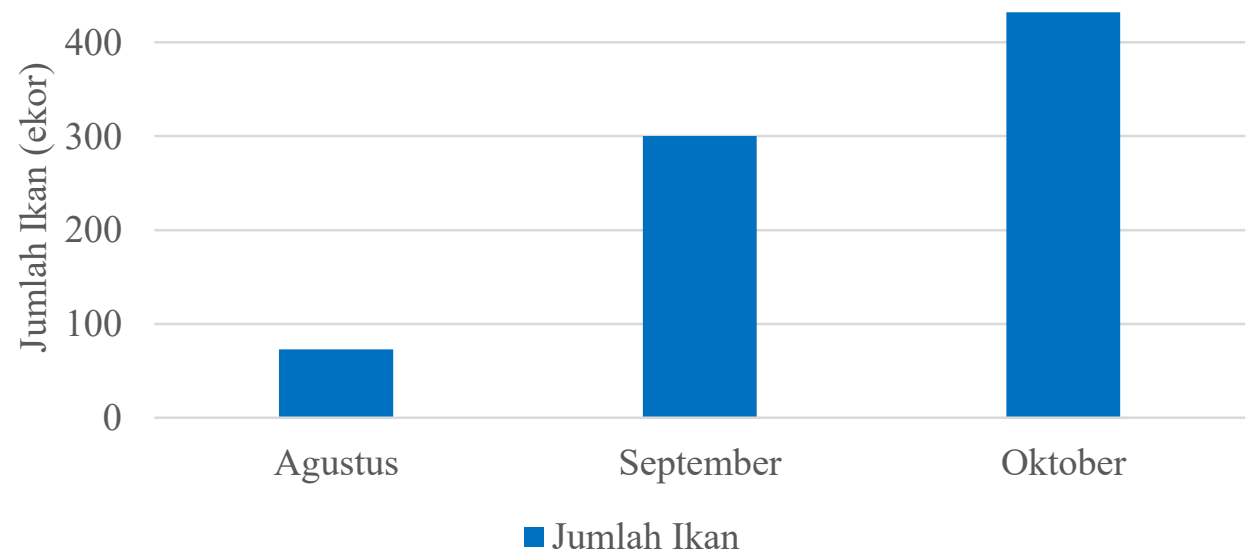

Gambar 4. Jumlah Ikan yang Dijual.

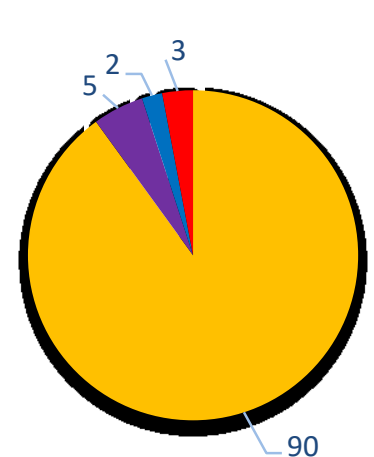

(a)

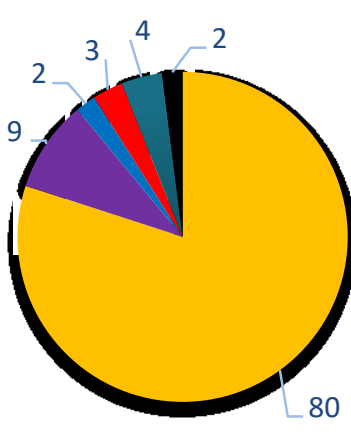

(b)

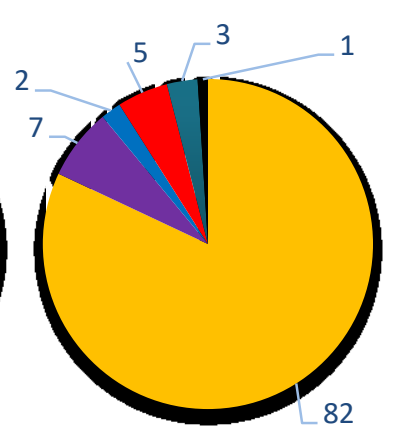

(c)
Kota Pangkalpinang

- Kab. Bangka

- Kab. Bangka Tengah

- Kab. Bangka Barat

- Kab. Bangka Selatan

- Di Luar Pulau Bangka

Gambar 5. Jangkauan Daerah Pemasaran di Bulan Agustus (a), September (b), dan Oktober (c). 
Kegiatan entreprenurship yang dilakukan oleh alumni Jurusan Akuakultur, Universitas Bangka Belitung dapat menjadi salah satu usaha yang berpotensi untuk dikembangkan. Hal ini terlihat dari perkembangan penjualan dan permintaan pembeli terhadap ikan cupang yang dijual oleh Exotic Betta. Potensi permintaan ini perlu dikelola dengan baik sehingga omset usaha terus meningkat. Beberapa hal yang dapat dilakukan adalah fokus pada penjualan ikan cupang sehingga menjadi ciri khas di dalam branding Exotic Betta. Hal ini dapat menguntungkan ketika pembeli atau hobiis telah menjadikan Exotic Betta sebagai satu-satunya referensi ikan cupang di Pulau Bangka sehingga penjualan dapat meningkat meskipun terdapat usaha lainnya yang sejenis. Hal lain yang dapat dilakukan di dalam peningkatan pemasaran adalah diversifikasi produk usaha, yaitu ikan hias lainnya sebagai bagian dari strategi pemasaran (marketing strategy) untuk mempertahankan eksistensinya. Hal ini dikarenakan permintaan ikan hias, khususnya ikan cupang hanya diminati oleh hobiis dan bersifat musiman [4] sehingga diperlukan upaya untuk menjaga ataupun meningkatan omset keuntungan. Diversifikasi komoditas dipandang sebagai usaha untuk meningkatkan keuntungan dengan cara turut memproduksi atau memasarkan komoditas lainnya yang juga memiliki nilai ekonomi tinggi [5]. Oleh karena itu untuk menjaga kontinyuitas pemasaran, maka pengembangan usaha ikan hias lainnya juga dibutuhkan untuk memperluas jangkauan segmetasi pembeli.

\section{KESIMPULAN DAN SARAN}

Kegiatan pengabdian kepada masyarakat berupa pendampingan yang dilakukan mampu memberikan dorongan semangat bagi alumni untuk memulai dan mewujudkan usaha ikan cupang. Pentahapan proses dilakukan secara konsisten selama kegiatan pendampingan sehingga dapat berkontribusi bagi terciptanya suasana kebersamaan yang mempercepat pencapaian sasaran yang ditargetkan.

\section{DAFTAR PUSTAKA}

[1] Basri, A.S.H., 2011, Eksistensi dan Peran Alumni dalam Menjaga Kualitas Mutu Fakultas Dakwah. Jurnal Dakwah, No. 1, Vol. 12, 137-158.

[2] Yohnson, Y., 2003, Peranan Universitas dalam Memotivasi Sarjana Menjadi Young Entrepreneurs (Seri Penelitian Kewirausahaan). Jurnal Manajemen dan Kewirausahaan, No. 2, Vol. 5, 97-111.

[3] Shamadiyah, N., 2017, Analisis SWOT Strategi Pemberdayaan Masyarakat Program Penataan Lingkungan Permukiman Komunitas di Kelurahan Suryatmajan, Kota Yogyakarta. Jurnal AGRIFO, No. 1, Vol. 2, 1-9.

[4] Elpita, D., Hendrik., Hamid., 2017, Ornamental Fish Marketing And Aquarium Equipment in Pekanbaru Riau Province. JOM, No. 1, Vol. 4, 1-9.

[5] Gandhy, A., 2017, Analisis Peningkatkan Pendapatan Petani Keramba Jaring Apung dengan Diversifikasi Spesies Ikan Budidaya di Waduk Cirata. Jurnal Ekonomi \& Studi Pembangunan, No. 1, Vol. 18, 25-33. 